Research article

urn:1sid:zoobank.org:pub:F5F578C8-4CA7-4ADA-9DAF-0DA5170E9F9F

\title{
Two new genera and nine new species of hydroids (Cnidaria: Hydrozoa) from off New Caledonia
}

\author{
Horia R. GALEA \\ Hydrozoan Research Laboratory, 405 Chemin des Gatiers, 83170 Tourves, France. \\ E-mail: horia.galea@gmail.com \\ urn:1sid:zoobank.org:author:DE5AC672-0243-46F2-A910-AFF4E91A4C5D
}

\begin{abstract}
Two new genera and nine new species of hydroids are described based on deep-water material collected from off New Caledonia during various expeditions of the French Tropical Deep-Sea Benthos program. Caledoniana gen. nov., provisionally included in the family Sertulariidae Lamouroux, 1812, presently comprises three new species, viz. C. alata sp. nov., C. decussata sp. nov., and C. microgona sp. nov., while an additional group of three new species, is accommodated in the new sertulariid genus Solenoscyphus gen. nov.: S. candelabrum sp. nov., S. decidualis sp. nov., and S. striatus sp. nov. Furthermore, three new species of Hincksella Billard, 1918 (family Syntheciidae MarktannerTurneretscher, 1890) are described, namely $H$. cornuta sp. nov., $H$. neocaledonica sp. nov., and H. similis sp. nov.
\end{abstract}

Key words. New species, western Pacific, deep-water.

Galea H.R. 2015. Two new genera and nine new species of hydroids (Cnidaria: Hydrozoa) from off New Caledonia. European Journal of Taxonomy 135: 1-19. http://dx.doi.org/10.5852/ejt.2015.135

\section{Introduction}

Large collections of hydroids were gathered during numerous French expeditions, conducted conjointly by the Institut de Recherche pour le Développement (IRD, formerly ORSTOM) and the Muséum national d'Histoire naturelle (MNHN) of Paris, in the tropical southwestern Pacific. Launched early in the 1980's as the MUSORSTOM campaigns and continuing until today under the name Tropical Deep-Sea Benthos, these expeditions aimed at exploring the deep-sea fauna (down to $1500 \mathrm{~m}$ ) of a vast geographical area extending from Taiwan to the Marquesas, and encompassing the Philippines, the Banda Sea, the Solomon Islands, New Caledonia, Vanuatu, Wallis and Futuna, Fiji, Tonga, and the Austral Islands (Bouchet et al. 2008).

Accounts of some genera and/or families of hydroids secured by these expeditions have already been published over the last two decades: Sertulariidae and, to a much lesser extent, Thyroscyphidae (Vervoort 1993), Halopterididae (Ansín Agís et al. 2009), Acryptolaria (Peña Cantero \& Vervoort 2010), and Kirchenpaueriidae (Ansín Agís et al. 2014).

A collection of specimens not studied by Vervoort (1993) or collected after the publication of his monograph, comprising species belonging to various genera of Sertulariidae, Syntheciidae, 
Thyroscyphidae, Campanulariidae, and Haleciidae, was entrusted to me for study. The present report is the first account, based on a fraction of the material in this collection, and deals particularly with nine new species of hydroids, of which six are accommodated in two new genera of sertulariids, while the remaining three belong to the syntheciid genus Hincksella Billard, 1918.

\title{
Material and methods
}

The methods of study were described in detail by Galea $(2007,2008)$. Station numbers, as indicated in the text, are preceded by a two-letter prefix referring to the sampling gear used to secure the material, either a Warén dredge (DW) or a beam trawl (CP). The material is deposited in the collections of MNHN.

\section{Results}

\author{
Phylum Cnidaria Verrill, 1865 \\ Class Hydrozoa Owen, 1843 \\ Subclass Hydroidolina Collins \& Marques, 2004 \\ Order Leptothecata Cornelius, 1992 \\ Family Sertulariidae Lamouroux, 1812 \\ Genus Caledoniana gen. nov. \\ urn:lsid:zoobank.org:act:7D2C6D92-C02C-4977-A568-4A5F277389A4
}

\section{Diagnosis}

Erect, loosely-branched, fan-shaped, weakly-fascicled colonies; branching pattern sparing and irregular; division into internodes indistinct; hydrothecae given off in opposite, though not contiguous pairs, except for the first hydrothecae of the side branches which are unpaired; successive pairs of hydrothecae either coplanar or, occasionally, adopting a decussate arrangement; hydrothecae very large, tubular, free for at least half their length, closed by rounded, deciduous opercula; gonothecae club-shaped to piriform, inserted slightly laterally, below the hydrothecal bases.

\section{Etymology}

Named after the area of occurrence of its species, New Caledonia. The genus name is a feminine noun.

\section{Type species}

Caledoniana alata sp. nov.

\section{Remarks}

The new genus is provisionally placed within the family Sertulariidae owing to the presence of hydrothecal opercula, though molecular analyses, based on freshly-collected samples, are needed to confirm this.

Together with Gigantotheca Vervoort \& Watson, 2003, Caledoniana gen. nov. is distinguished from other genera through the presence of huge, tubular hydrothecae, both genera forming a clearly distinct group within the family. Unlike Gigantotheca, in which the hydrothecae are alternate, those of Caledoniana gen. nov. are grouped in opposite pairs, analogous to the generic separation of Hincksella Billard, 1918 and Synthecium Allman, 1872, respectively, in the family Syntheciidae.

The hydrothecae of Caledoniana gen. nov. superficially resemble those of Staurotheca Allman, 1888, especially through the presence of deciduous opercula with no definite points of attachment (see Peña Cantero et al. 1997: 336). However, the hydrothecae of the latter are arranged in two or multiple 
longitudinal rows, they are generally deeply immersed in both stems and branches, and their size is much smaller in all species described so far (Peña Cantero et al. 1997, 1999; Peña Cantero \& Vervoort 2003a, 2003b).

Staurotheca megalotheca Vervoort \& Watson, 2003, a species of so far uncertain generic position, possesses huge hydrothecae arranged in either opposite pairs or decussate groups of three (Vervoort \& Watson 2003), suggesting obvious affinities with Caledoniana gen. nov., in particular with C. decussata sp. nov. (see below).

\section{Key to species}

1. Free part of hydrothecae curved upward ................................... alata sp. nov.

- Free part of hydrothecae straight .2

2. Some pairs of hydrothecae adopting a decussate arrangement .............. decussata sp. nov.

- Successive pairs of hydrothecae always coplanar ...................... microgona sp. nov.

Caledoniana alata sp. nov.

urn:1sid:zoobank.org:act:9B3A55AF-D726-41DA-AA96-B3D8B9836BC5

Figs 1A, 2A-B; Table 1

\section{Diagnosis}

Colonies lightly fascicled basally, loosely branched, coplanar; nodes indistinct, internodes short; hydrothecae in opposite pairs and coplanar series; long, tubular, free part distinctly curved upward; gonothecae large, piriform.

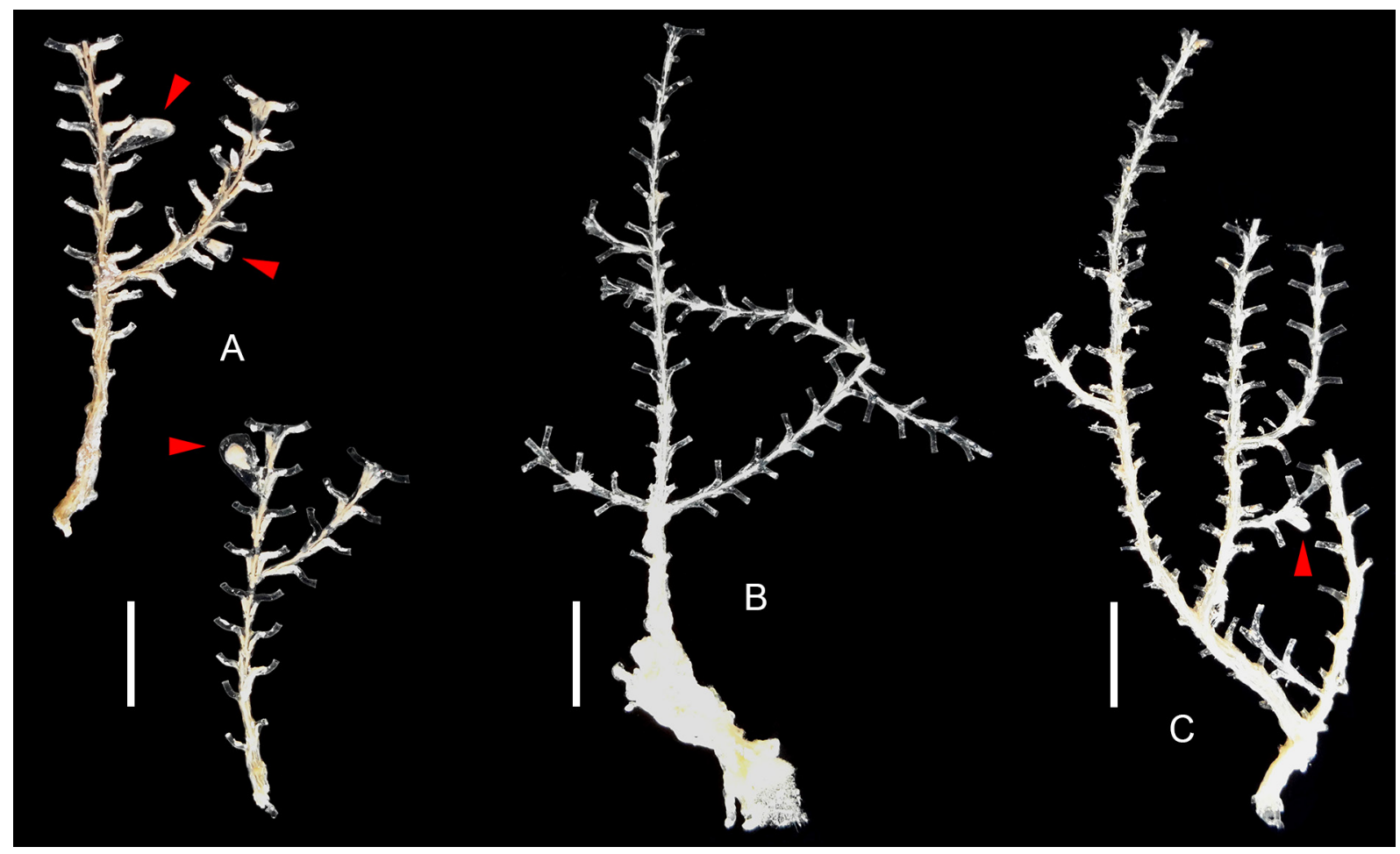

Fig. 1. A. Caledoniana alata gen. et sp. nov., holotype (below) and paratype (above). B. Caledoniana decussata gen. et sp. nov., colony silhouette (part of holotype). C. Caledoniana microgona gen. et sp. nov., colony silhouette (holotype). The red arrows indicate the presence of gonothecae. Scale bars: $1 \mathrm{~cm}$. 


\section{Etymology}

From the Latin àlātus, meaning "winged", making reference to the shape of the hydrothecae, recalling the wings of a gliding bird.

\section{Type material}

\section{Holotype}

NEW CALEDONIA: campaign Bathus 4, station DW923, 185' S, 16324' E, 502-470 m, 6 Aug. $1994 ; 3.6 \mathrm{~cm}$ high, branched fragment bearing a mature gonotheca (IK-2012-10287).

\section{Paratype}

NEW CALEDONIA: data as for holotype; $4.6 \mathrm{~cm}$ high, branched fragment bearing a mature and an immature gonotheca (IK-2012-10288).

\section{Description}

Two stem fragments, 3.6 and $4.6 \mathrm{~cm}$ high, with no hydrorhizae, possibly detached at base from same colony; lightly fascicled proximally, with a few accessory tubes creeping over main tube bearing hydrothecae. No evident division into internodes, even in monosiphonic parts. Each equivalent of internode short, accommodating pair of opposite, though not contiguous, hydrothecae. Single side branches, given off laterally from below a stem hydrotheca, occur in both specimens; structure similar to that of stem, except for first hydrotheca, which is unpaired. Hydrothecae large, tubular, immersed for about half their length into their corresponding internodes; free parts bent at nearly right angles to internodes, then curving upwards toward their middle; diameter nearly constant for most of length, slightly expanding toward aperture; rim with thickened perisarc; in frontal view, aperture semi-circular on adaxial side and somewhat flattened on abaxial side; a filmy, rounded operculum observed in one hydrotheca, but opercula likely deciduous. Gonothecae large and pyriform, with no distinct aperture; at least three large, globular structures (oocytes or young embryos) present in one of them. Numerous, large foramina (obliterated by thin pellicle of perisarc) below each hydrotheca suggest that gonothecae may occur in pairs in fully fertile specimens. Coenosarc badly preserved, not suitable for tentacle counting or cnidome studies.

\section{Remarks}

The hydrothecae are so large that sand grains partially or totally fill their lumina. In this case, the finding of an operculum closing the aperture of a hydrotheca is truly fortunate.

Caledoniana decussata sp. nov. urn:1sid:zoobank.org:act:B302DBC1-9E6F-427F-A3B6-3843F8FAE77C

Figs 1B, 2C-D; Table 1

\section{Diagnosis}

Colonies lightly fascicled basally, loosely branched, coplanar; nodes indistinct, internodes relatively short; hydrothecae in opposite pairs in both coplanar and decussate series; long, tubular, free part straight.

\section{Etymology}

From the Latin décusso, meaning "to form or create a cross in the form of an X", to characterize the arrangement of the hydrothecal pairs in this species. 


\section{Material examined}

\section{Holotype}

NEW CALEDONIA: campaign Bathus 2, station CP737, 230' S, $167^{\circ} 00^{\prime}$ E, 357-400 m, 13 May 1993; $5.5 \mathrm{~cm}$ high, sterile colony attached to mineral concretion and adjacent sponge, as well as 3 smaller fragments detached from it (IK-2012-10289).

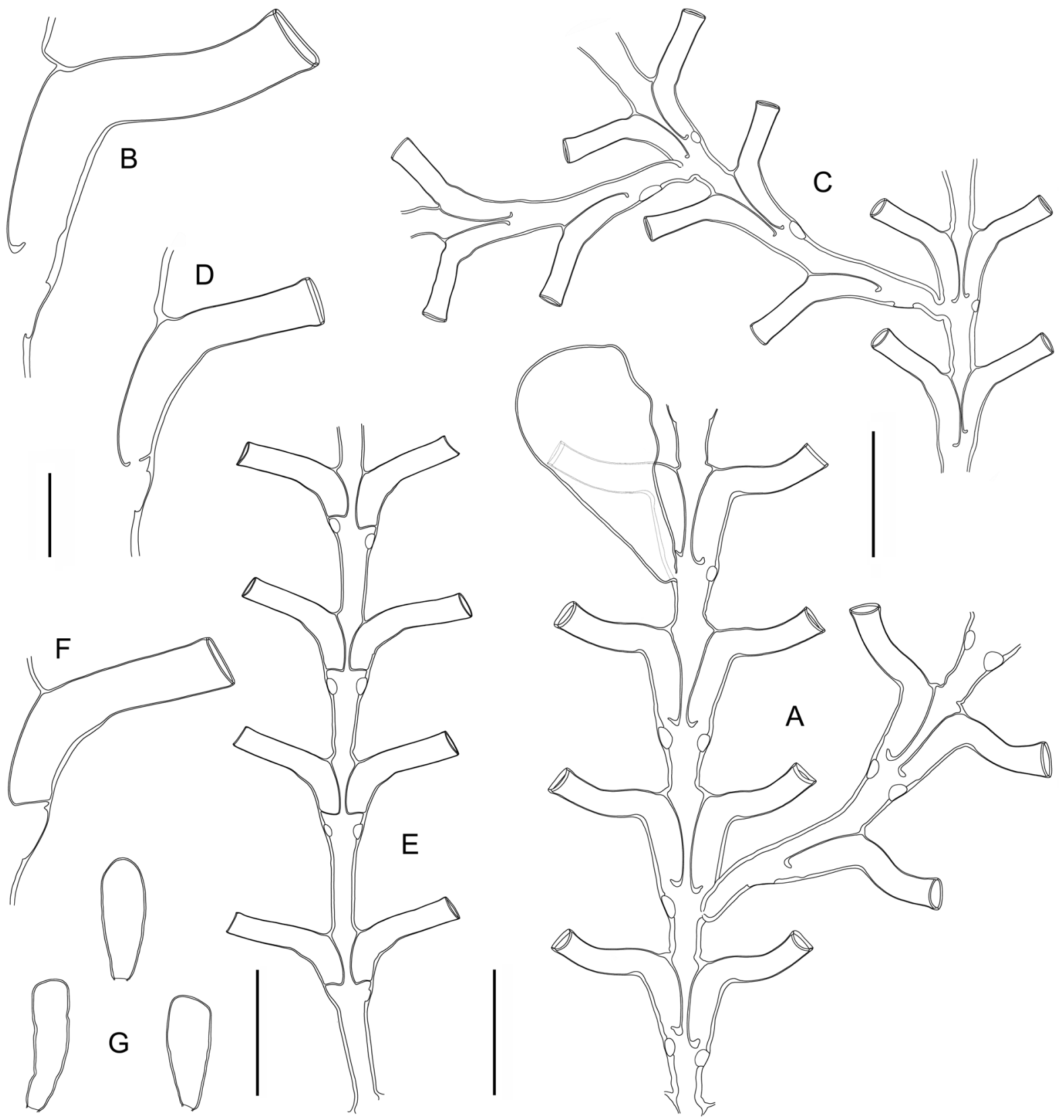

Fig. 2. - A-B. Caledoniana alata gen. et sp. nov. A. Portion of fertile stem (note gonotheca above) and basal part of a side branch, showing positions of hydrothecae. B. Hydrotheca. - C-D. Caledoniana decussata gen. et sp. nov. C. Portion of stem with first and second order side branches from region of colony with coplanar hydrothecae, showing their relative position. D. Hydrotheca. - E-G. Caledoniana microgona gen. et sp. nov. E. Portion of stem. F. Hydrotheca. G. Three gonothecae. Scale bars: A, C, E, $\mathrm{G}=3 \mathrm{~mm} ; \mathrm{B}, \mathrm{D}, \mathrm{F}=1 \mathrm{~mm}$. 


\section{Description}

Colony erect, $5.5 \mathrm{~cm}$ high, arising from rhizoid stolon firmly attached to substrate. Basal part of stem fascicled, with several accessory tubes creeping over main tube; in monosiphonic parts, division into internodes indistinct; each equivalent of internode relatively short, bearing a pair of opposite, though not contiguous, hydrothecae. Branching sparse and irregular, up to $2^{\text {nd }}$ order; side branches given off singly or in pairs from below a stem hydrotheca; stem and side branches coplanar; structure of latter similar to that of stem, except for first hydrotheca, which is usually unpaired, though a pair of hydrothecae also occurs within colony. Basal parts of stem and side branches with successive pairs of hydrothecae in coplanar series; more distally, pairs become decussate. Hydrothecae large, tubular, adnate for about half of length, or less, to corresponding internodes; free part bent at about $45^{\circ}$; diameter nearly constant throughout, slightly expanding at rim; rim conspicuously thickened; aperture circular in frontal view; opercula not seen. Gonothecae absent, though basal remains at insertion of one of these (below a hydrotheca) present; numerous, large foramina (obliterated by thin pellicle of perisarc) below most hydrothecae, making the possibly future insertion points for them. Coenosarc badly preserved, not suitable for tentacle counting or cnidome studies.

\section{Caledoniana microgona sp. nov. urn:1sid:zoobank.org:act:798CB04B-5AB6-48B2-962D-AD9F6FE56D65}

Figs 1C, 2E-G; Table 1

\section{Diagnosis}

Colonies lightly fascicled basally, loosely branched, coplanar; nodes indistinct, internodes relatively long; hydrothecae in opposite pairs and coplanar series; long, tubular, free part slightly convex basally, then straight; gonothecae small, club-shaped.

\section{Etymology}

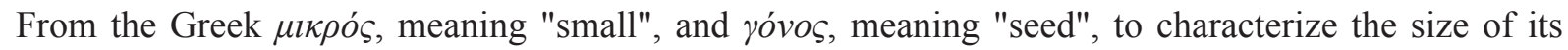
gonothecae.

\section{Material examined}

Holotype

NEW CALEDONIA: campaign Biocal, station DW46, 2253’ S, 167¹7' E, 570-610 m, 30 Aug. 1985; $7.3 \mathrm{~cm}$ high colony with one gonotheca (IK-2012-10290).

\section{Paratypes}

NEW CALEDONIA: data as for holotype; numerous fragmented stems up to $6.3 \mathrm{~cm} \mathrm{high,} \mathrm{some} \mathrm{sterile,}$ as well as several detached gonothecae (IK-2012-10291).

\section{Description}

Colonies erect, up to $7 \mathrm{~cm}$ high, fan-shaped, loosely fascicled on basal portions of stems and some lower side branches. Main tube indistinctly divided into moderately long internodes, each of them bearing a distal pair of opposite, though not contiguous, hydrothecae. Side branches sparse, given off irregularly and laterally from below a hydrotheca; up to $2^{\text {nd }}$ order branching. First hydrotheca of side branch commonly unpaired, although one colony with paired hydrothecae. Hydrothecae large and tubular, immersed for about one-third of adaxial length into internode; free part of nearly constant diameter, projecting outward at wide angle; abaxial wall slightly tumid at inflexion point, then straight distally; free adaxial side slightly convex basally, then parallel to abaxial counterpart; rim thickened; aperture borne on slight terminal constriction of hydrothecal wall; in frontal view rounded on adaxial side and flattened abaxially; opercula not seen. Gonothecae given off slightly laterally from below bases 
Table 1. Measurements of species of Caledoniana gen. nov., in $\mu \mathrm{m}$.

\begin{tabular}{lccc}
\hline & C. alata sp. nov. & C. decussata sp. nov. & C. microgona sp. nov. \\
\hline Stem & & & \\
"Internode" length & $3500-4000$ & $2500-3000$ & $3000-3700$ \\
Diameter at "node" & $675-735$ & $530-665$ & $445-665$ \\
Hydrotheca & & & \\
Adaxial side free & $2265-2530$ & $1730-1875$ & $2100-2475$ \\
Adaxial side adnate & $1980-2420$ & $1620-1830$ & $1170-1420$ \\
Abaxial side & $3845-4130$ & $2860-3075$ & $2630-2955$ \\
Width & $615-725$ & $465-510$ & $530-590$ \\
Diameter at rim & $650-870$ & $515-550$ & $495-605$ \\
Gonotheca & & & \\
Length & 6250 (gonotheca \#1) & - & $2750-3250$ \\
Maximum width & 6750 (gonotheca \#2) & & $1040-1160$ \\
& 3300 (gonotheca $\# 1)$ & - & \\
\hline
\end{tabular}

of hydrothecae; small and club-shaped, with thick perisarc. Coenosarc badly preserved, not suitable for tentacle counting or cnidome studies.

\section{Remarks}

Like in $C$. decussata gen. et sp. nov., the free parts of the hydrothecae of this species are almost straight, thus differing from the sigmoid shape met with in C. alata gen. et sp. nov. However, in C. decussata gen. et sp. nov. the hydrothecal pairs may exhibit a decussate arrangement; their free part is comparatively shorter, while the adnate one is longer.

Genus Solenoscyphus gen. nov.

urn:Isid:zoobank.org:act:B69365F9-2052-4A94-8AF4-2456E46DA678

\section{Diagnosis}

Colonies of various sizes and shapes, from irregularly branched to pinnate, with either mono- or polysiphonic stems; cladia always monosiphonic. Hydrothecae long, tubular, with either straight or curved axes, adnate for less than half their length to the internodes; bases as complete septa; opercula filmy and rounded in shape, with indistinct points of attachment, clearly deciduous. Perisarc either smooth or finely and densely striated. Gonothecae unknown.

\section{Type species}

Solenoscyphus candelabrum sp. nov.

\section{Etymology}

From the Greek $\sigma \omega \lambda \eta v o \varepsilon l \delta \dot{\eta} \varsigma$, meaning "tubular", and $\sigma \kappa v ́ \varphi o \varsigma$, meaning "cup", to characterize the shape of the hydrothecae. It is a masculine noun.

\section{Remarks}

Unlike other sertulariid genera whose hydrothecae are provided with either an adaxial (Abietinaria Kirchenpauer, 1884, Diphasia Agassiz, 1862, Idiellana Cotton \& Godfrey, 1942, and Papilionella 
Antsulevich \& Vervoort, 1993) or an abaxial (Salacia Lamouroux, 1816 and Thuiaria Fleming, 1828) opercular flap (Bouillon et al. 2006), the new genus possesses a deciduous operculum with no definite point of attachment.

In this respect, it shows similarities with both Caledoniana gen. nov. and Staurotheca Allman, 1888, and this may prove to be equally true for Gigantotheca Vervoort \& Watson, 2003 as well. As shown above, Caledoniana gen. nov. is characterized by the presence of huge hydrothecae, a situation not met with in any of the three species described below. On the other hand, Staurotheca comprises a majority of species exhibiting a characteristic arrangement of the hydrothecae in decussate groups, although in a few cases they are either subopposite (S. amphorophora Naumov \& Stepanjants, 1962, S. australis Peña Cantero et al., 1997, and S. vervoorti El Beshbeeshy, 2011) or decidedly alternate (S. abyssalis Peña Cantero \& Vervoort, 2003 and S. profunda Peña Cantero \& Vervoort, 2003). In addition, the hydrothecae of most species of Staurotheca are deeply immersed in both the stem and side branches; they characteristically curve outwards and their bases are often incomplete septa. Moreover, the colony shape in that genus is radically different, ranging from bush-like (with no distinct stems) to fan-shaped or tree-like (Peña Cantero \& Vervoort 2003a). Unlike the tropical Solenoscyphus gen. nov., Allman's (1888) genus is essentially Antarctic, with a few species also occurring in the sub-Antarctic and some localities in South America (Peña Cantero \& Vervoort 2003a).

\section{Key to species}

1. Free part of hydrothecae curved upward …......................... candelabrum sp. nov.

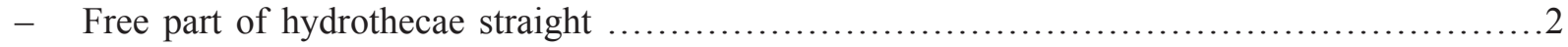

2. Perisarc striated throughout, apex of hydrotheca swollen ...................S. striatus sp. nov.

- Perisarc smooth, hydrotheca isodiametric throughout .................... decidualis sp. nov.

Solenoscyphus candelabrum sp. nov.

urn:1sid:zoobank.org:act:88847458-73D4-42B1-B553-4AD070BC2AFA

Figs 3A, 4A-B; Table 2

\section{Diagnosis}

Colonies regularly pinnate, stems polysiphonic, cladia always monosiphonic; nodes indistinct; stem internodes composed of an apophysis, an axillary hydrotheca, two alternate hydrothecae above, another apophysis opposite to the former, and an axillary hydrotheca; cladial internodes, each with one hydrotheca; hydrothecae alternate throughout, long, tubular, free part distinctly concave, facing upward; operculum deciduous.

\section{Etymology}

From the Latin candèläbrum, meaning "candlestick", with reference to the shape of the hydrothecae, the whole colony resembling a phantasmagoric candelabrum with an infinity of arms. Used as a noun in apposition.

\section{Material examined}

\section{Holotype}

NEW CALEDONIA: campaign Bathus 4, station DW923, 1852' S, 163²4' E, 502-470 m, 6 Aug. 1994; $9.0 \mathrm{~cm}$ high, sterile colony (IK-2012-10292).

\section{Paratypes}

NEW CALEDONIA: data as for holotype; four sterile colonies 5.7-12.0 cm high (IK-2012-10293). 


\section{Description}

Stems up to $12 \mathrm{~cm}$ high, arising from disc-shaped hydrorhizae firmly attached to substrate; strongly polysiphonic basally, uniformly grading to monosiphonic towards apices; auxiliary tubes running up, nearly parallel to main tube and establishing occasional anastomoses with each other. Nodes generally poorly indicated, though division into internodes with apparently unusual repetitive sequence: proximal node, short lateral apophysis (supporting a cladium), axillary hydrotheca, two alternate hydrothecae above, second cladial apophysis on opposite side to former, axillar hydrotheca, and distal node. Cladia pinnately arranged, given off at about $70^{\circ}$ to stem, up to $3 \mathrm{~cm}$ long; straight, unbranched, exclusively monosiphonic; inserting on corresponding stem apophyses by means of short, rectangular, ahydrothecate internodes; nodes indistinct. Hydrothecae of both stem and cladia biseriate, alternate, and coplanar; tubular, S-shaped, facing out- and upward; a prominent internal perisarc thickening occurring along median line of lower half of abaxial wall, together with a transverse ridge arising from middle part of perisarcal thickening, and extending over both "frontal" and "dorsal" sides of theca; elsewhere perisarc relatively thin; in frontal view, aperture of hydrotheca rounded adaxially and slightly flattened abaxially; deciduous opercula rarely seen at apertures of some hydrothecae. Gonotheca unknown.

Solenoscyphus decidualis sp. nov. urn:1sid:zoobank.org:act:E4FDE6E2-065E-43CC-B978-126563826AA9

Figs 3B, 4C-D; Table 2

\section{Diagnosis}

Colonies regularly pinnate, stems polysiphonic, cladia always monosiphonic; nodes indistinct; stem internodes composed of two alternate hydrothecae, an apophysis, and an axillary hydrotheca; cladial internodes each with one hydrotheca; the latter alternate, long, tubular, free part slightly convex basally, then straight; operculum deciduous.

\section{Etymology}

From the Latin dēcídŭus, meaning "deciduous", with reference to the condition of the hydrothecal operculum.

\section{Material examined}

\section{Holotype}

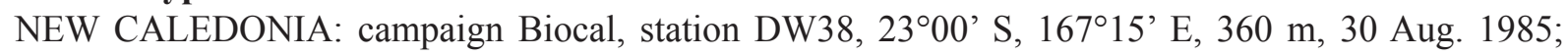
$4.0 \mathrm{~cm}$ high, sterile colony (IK-2012-10294).

\section{Description}

Essential part of hydrorhiza missing, but remains of what appears to be a rhizoid stolon, firmly attached to substrate, could be seen. Colony erect and pinnate, $c a .4 \mathrm{~cm}$ high. Stem lightly fascicled basally, grading to monosiphonic distally; auxiliary tubes fused to one another, forming outer layer of perisarc enveloping main tube; monosiphonic part of stem with indistinct nodes; equivalents of internodes composed of proximal "node", two alternate hydrothecae, short lateral apophysis (supporting cladium) on side opposite to second hydrotheca, axillary hydrotheca, and distal "node". Cladia up to $1.2 \mathrm{~cm}$ long, inserted on corresponding stem apophyses, occurring at an angle of about $70^{\circ}$ with stem; nodes indistinct; equivalents of internodes relatively short, each carrying a hydrotheca on its distal half. Hydrothecae of both stem and cladia biseriate, alternate, given off at $70-75^{\circ}$ to "internodes"; tubular, adnate for onefourth of adaxial length; both free adaxial and abaxial walls parallel, imperceptibly convex to almost straight; rim even, aperture circular, placed at right angle to axis of theca; rare, rounded opercula close apertures of some hydrothecae. Gonotheca unknown. 
Solenoscyphus striatus sp. nov.

urn:1sid:zoobank.org:act:6ED544D2-AD80-469D-AF97-DFE1062D6E0D

Figs 3C, 4E-G; Table 2

\section{Diagnosis}

Colonies lightly fascicled basally; branching irregular, in one plane; nodes indistinct; each internode relatively short, bearing a hydrotheca; the latter long, tubular, facing outward and upward, apically swollen; operculum deciduous; perisarc of colonies densely and finely striated.

\section{Etymology}

From the Latin strīatus, meaning "marked with striae", to characterize the external condition of the perisarc.

\section{Material examined}

\section{Holotype}

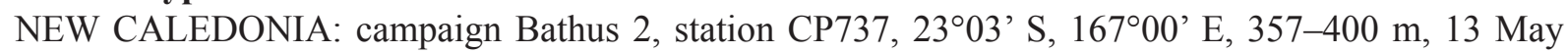
1993; sterile colony fragment $5.2 \mathrm{~cm}$ high (IK-2012-10295).

\section{Paratype}

NEW CALEDONIA: data as for holotype; sterile colony fragment $3.1 \mathrm{~cm}$ high (IK-2012-10296).

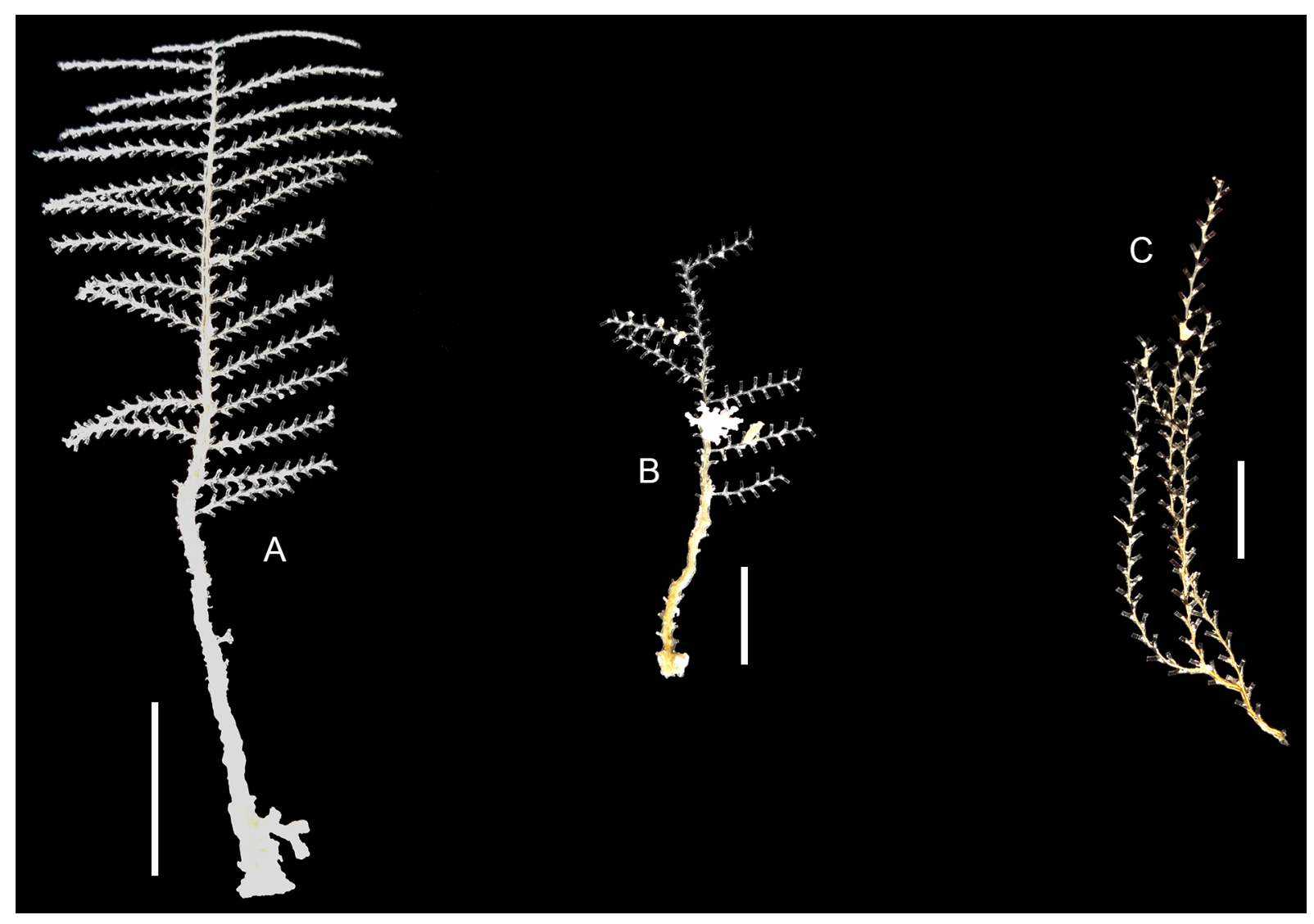

Fig. 3. A. Solenoscyphus candelabrum gen. et sp. nov., colony silhouette (holotype). B. Solenoscyphus decidualis gen. et sp. nov., colony silhouette (holotype). C. Solenoscyphus striatus gen. et sp. nov., colony silhouette (holotype). Scale bars: $\mathrm{A}=2 \mathrm{~cm} ; \mathrm{B}-\mathrm{C}=1 \mathrm{~cm}$. 


\section{Description}

Smaller specimen (paratype) $3.1 \mathrm{~cm}$ high, comprising a branched fragment of either a stem or a side branch; larger specimen (Fig. 3C, holotype) $5.2 \mathrm{~cm}$ high, possibly a branched stem missing hydrorhiza;

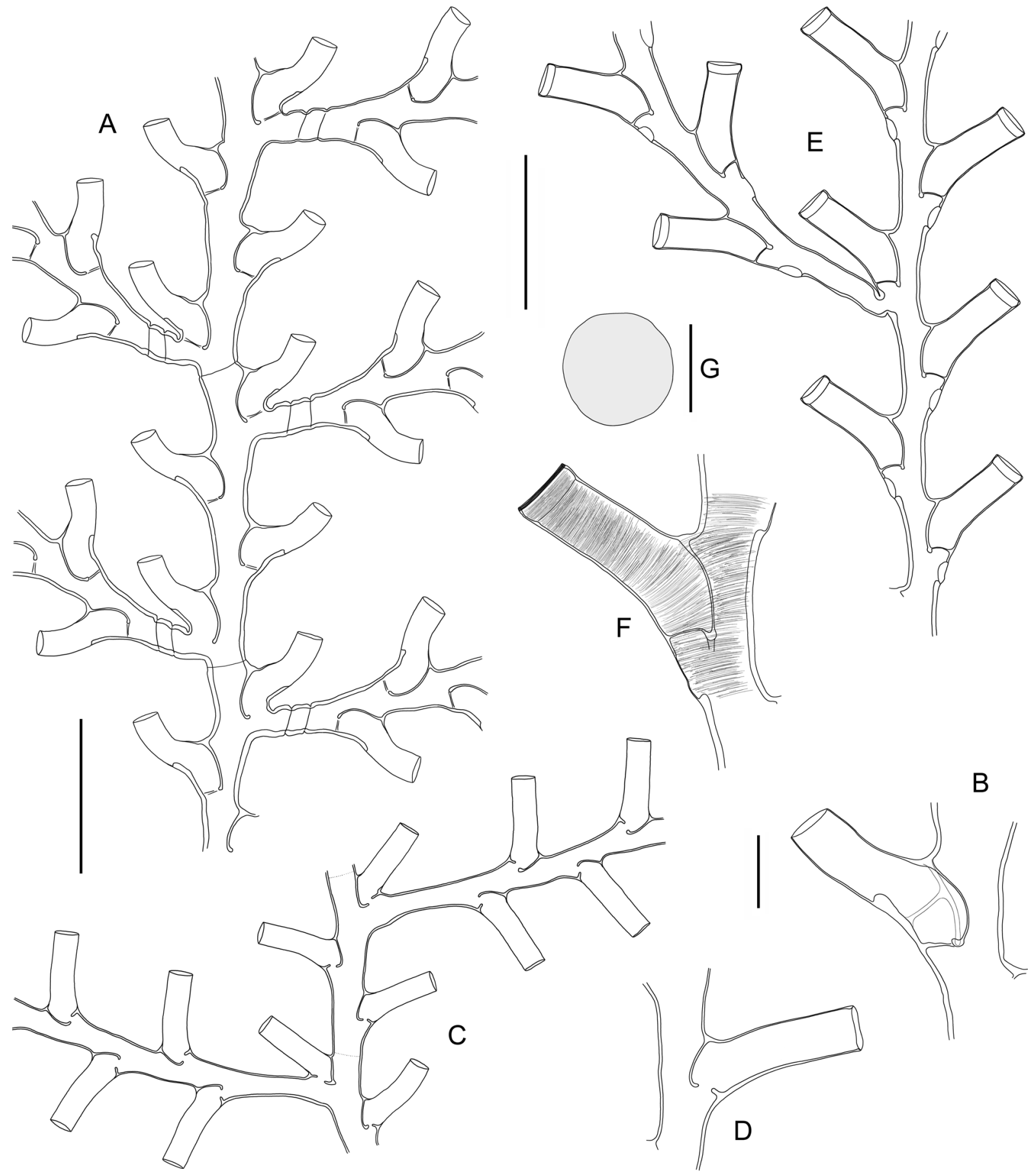

Fig. 4. - A-B. Solenoscyphus candelabrum gen. et sp. nov. A. Portion of stem with basal parts of five cladia. B. Hydrotheca, showing internal projections of the perisarc. - C-D. Solenoscyphus decidualis gen. et sp. nov. C. Portion of stem with basal parts of two consecutive cladia. D. Hydrotheca. E-G. Solenoscyphus striatus gen. et sp. nov. E. Portion of stem with basal part of a side branch. F. Hydrotheca, showing the characteristic striation of the perisarc. G. Operculum. Scale bars: A, C, E = $2 \mathrm{~mm} ; \mathrm{B}, \mathrm{D}, \mathrm{F}=500 \mu \mathrm{m} ; \mathrm{G}=300 \mu \mathrm{m}$. 
Table 2. Measurements of species of Solenoscyphus gen. nov., in $\mu \mathrm{m}$.

\begin{tabular}{lccc}
\hline & S. candelabrum sp. nov. & S. decidualis sp. nov. & S. striatus sp. nov. \\
\hline Stem & & & \\
"Internode" length & $1085-1235$ & $830-925$ & $1170-1445$ \\
Diameter at "node" & $445-580$ & $390-440$ & $360-430$ \\
Cladial apophysis length & $385-445$ & - & - \\
Cladium & & & $1170-1445$ \\
"Internode" length & $815-990$ & $740-950$ & $360-430$ \\
Diameter at "node" & $445-580$ & $220-340$ & - \\
First athecate internode & $210-270$ & - & \\
Hydrotheca & & & $950-1075$ \\
Adaxial side free & $610-780$ & $975-1085$ & $590-655$ \\
Adaxial side adnate & $610-730$ & $335-395$ & $1335-1420$ \\
Abaxial side & $1085-1185$ & $1000-1075$ & $420-445$ \\
Maximum width & - & - & $295-335$ \\
Base width & - & - & $430-450$ \\
Diameter at rim & $315-355$ & $280-300$ & \\
\hline
\end{tabular}

both possibly originally parts of a single colony with multiple stems. This colony obviously fascicled to an unknown extent, as largest available fragment comprises an accessory tube running up both main stem and basal part of lowest side branch. Division into internodes indistinct; each equivalent of internode relatively short, carrying a single hydrotheca on distal half. Branching pattern irregular and sparing, with up to second order side branches given off laterally from below bases of hydrothecae; side branches with same structure as stem; proximal-most internode comparatively longer than following ones. Hydrothecae biseriate and alternate; tubular in shape, adnate for slightly more than one-third of adaxial length, facing up- and outward; abaxial wall almost straight, except for proximal part, which is convex at point where hydrotheca becomes free on opposite side; free adaxial side straight and parallel to adaxial counterpart. Apical part of hydrotheca distinctly swollen and there perisarc much thinner than elsewhere; rim indistinctly tilted adaxially; rounded, thin operculum present in some hydrothecae; point of attachment indeterminable; deciduous. External perisarc finely and densely striated over entire colony. Gonothecae unknown; scar below one hydrotheca suggests at least one gonotheca was present and subsequently lost; numerous large foramina (obliterated by thin pellicle of perisarc) indicate that colony was about to become fertile.

\section{Remarks}

Although not resembling either S. candelabrum gen. et sp. nov. or S. decidualis gen. et sp. nov. in colony shape, the present species nevertheless possesses a deciduous operculum, which is one of the main features of the newly described genus.

Unlike $S$. candelabrum gen. et sp. nov., both $S$. decidualis gen. et sp. nov. and the present species possess long, tubular hydrothecae with straight axes. However, their adnate parts are longer and their apertures are wider in S. striatus gen. et sp. nov. Additionally, the entire perisarc of the latter is finely and densely striated. 
Family Syntheciidae Marktanner-Turneretscher, 1890

Genus Hincksella Billard, 1918

\section{Key to species}

The following key comprises all species currently included in the genus Hincksella.

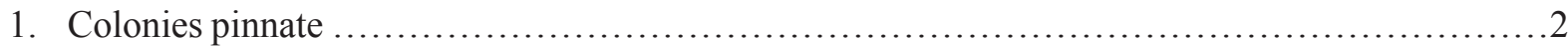

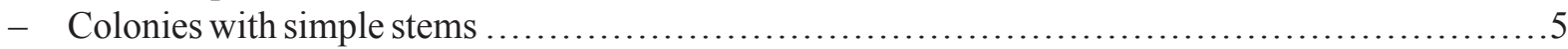

2. Hydrothecae shallow .............................................. sibogae Billard, 1918

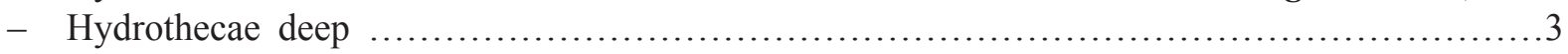

3. Hydrotheca adnate for one-third ............................. formosa (Fewkes, 1881)

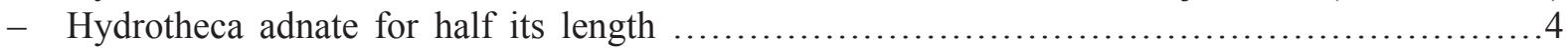

4. Free part facing outward ...................................... alternans (Allman, 1888)

- Free part facing upward ......................................... indiana Millard, 1967

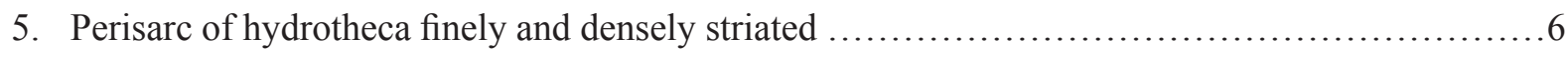

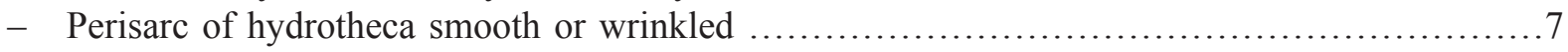

6. Hydrotheca making an almost right angle with the stem ....................... similis sp. nov.

- Hydrotheca making an acute angle with the stem .................... neocaledonica sp. nov.

7. Perisarc of hydrotheca wrinkled ...............................H. corrugata Millard, 1958

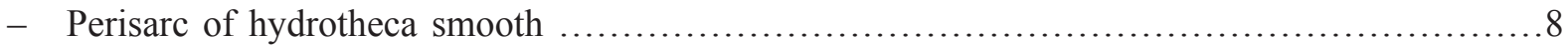

8. Hydrotheca exceedingly long .................................H. pusilla Ritchie, 1910

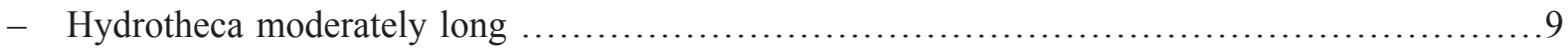

9. Aperture of hydrotheca facing outward ............................... cornuta sp. nov.

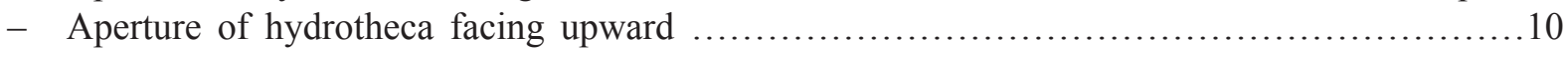

10. Hydrotheca isodiametric throughout ................................. projecta (Fraser, 1938)

- Margin of hydrotheca distinctly flaring .............................. rigida (Fraser, 1938)

Hincksella cornuta sp. nov. urn:lsid:zoobank.org:act:5DC46422-9914-47FF-8CE3-49AB51B0014A

Fig. 5A-D; Table 3

\section{Diagnosis}

Stems simple, monosiphonic, nodes indistinct; internodes relatively short, slightly geniculate, each carrying a hydrotheca; the latter alternate, tubular, bent in middle; rim often renovated; gonothecae arising from within the hydrothecae, broadly ovoid, lateral walls wrinkled; two prominent horns distally.

\section{Etymology}

From the Latin, cornūtus, meaning "horned", making reference to the prominent horns of the gonotheca. 


\section{Material examined}

\section{Holotype}

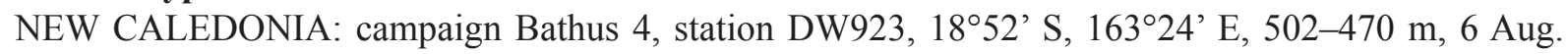
1994; whole stem $3.6 \mathrm{~cm}$ high, bearing two fully-formed gonothecae (IK-2012-10297).

\section{Paratypes}

NEW CALEDONIA: data as for holotype, four specimens $(3.1 \mathrm{~cm}$ high fragment with no basal part, bearing two gonothecae; $3.3 \mathrm{~cm}$ high fragment devoid of its basal part; entire, $4.0 \mathrm{~cm}$ high stem with one gonotheca; entire, sterile stem $3.8 \mathrm{~cm}$ high) (IK-2012-10298).

\section{Description}

Stems erect, up to $3.8 \mathrm{~cm}$ high, unbranched and monosiphonic, arising from tubular hydrorhizae; basal constriction at origin from stolon; lower parts ahydrothecate and quite long $(1.0-1.2 \mathrm{~cm})$, occasionally with signs of breakage and subsequent regeneration; perisarc smooth. Division by nodes indistinct, but equivalents of internodes rather short, slightly geniculate, bearing single hydrothecae on distal halves. Hydrothecae alternate, although the two proximal-most ones may be given off on same side of stem;
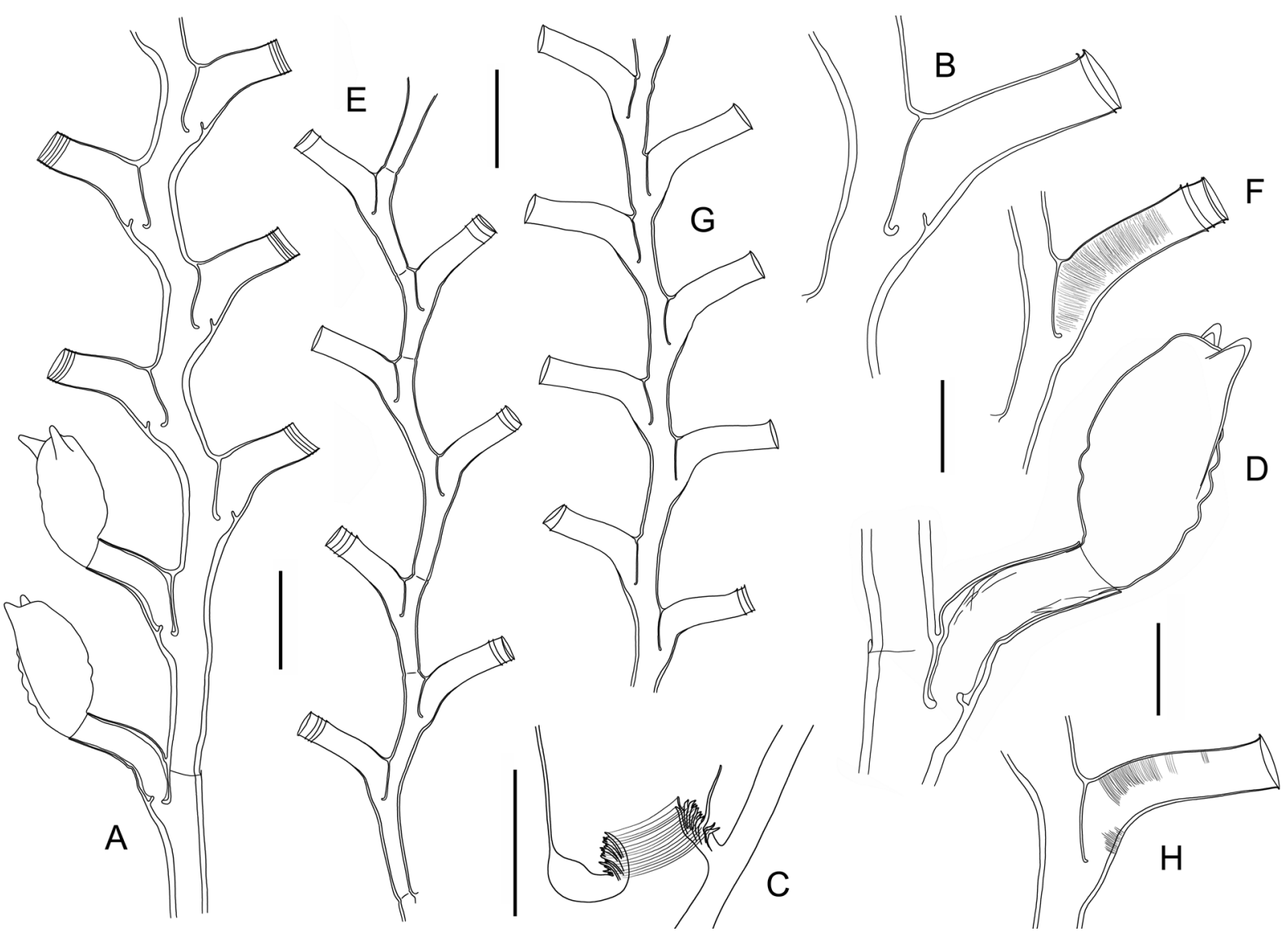

Fig. 5. - A-D. Hincksella cornuta sp. nov. A. Basal portion of stem with hydro- and gonothecae. B. Hydrotheca. C. Detail of the foramen for the passage of the hydranth into hydrotheca. D. Gonotheca arising from within a hydrotheca. - E-F. Hincksella neocaledonica sp. nov. E. Portion of stem. F. Hydrotheca, showing outer striations. - G-H. Hincksella similis sp. nov. G. Portion of stem. H. Hydrotheca, showing extent of external striations. Scale bars: A, E, G = 1 mm; B, D, F, H = $500 \mu \mathrm{m}$; $\mathrm{C}=200 \mu \mathrm{m}$. 
tubular, adnate for less than half of length; free part facing out- and upward; free adcauline wall slightly convex to almost straight; abcauline wall convex in middle and straight elsewhere; basal foramina with multiple renovations of perisarc (Fig. 5C); rim of hydrotheca often renovated; aperture circular, imperceptibly tilted adaxially. Hydranths enveloped by inner, thin, collapsible periderm, distinct from hydrothecal wall; tentacle number could not be counted. Gonothecae given off from within hydrothecae; broadly ovoid, with wrinkled perisarc, distally with two prominent horns; no signs of aperture; gonophore apparently single, large ovoid mass (oocyte?) occupying nearly entire lumen of gonotheca. Large macrobasic heteronemes (none seen discharged), with parallel walls and rounded ends, and with straight or slightly curved longitudinal axes, occur abundantly in coenosarc.

\section{Remarks}

The alternate, long, tubular, non-operculate hydrothecae, the gonothecae given off from within the hydrothecae, as well as the large macrobasic heteronemes (mastigophores?) scattered in the coenosarc place this species in the genus Hincksella Billard, 1918. The two horns on the distal part of its gonothecae distinguish this species from its congeners with known gonosomes, viz. H. alternans (Allman, 1888) (see original description), H. formosa (Fewkes, 1881) (see Galea 2013), H. pusilla Ritchie, 1910 (see Galea \& Ferry 2015), and H. sibogae Billard, 1918 (see Vervoort \& Watson 2003).

The remaining congeners with unknown gonothecae differ from $H$. cornuta sp. nov. in the following respects: 1) $H$. corrugata Millard, 1958 has comparatively shorter hydrothecae, adnate for as much as half their length, and their surface is transversely wrinkled (Millard 1958); 2) H. indiana Millard, 1967 is a much larger species, with fascicled stems, shorter hydrothecae, conspicuously tilted adaxially (Millard 1967); 3) the poorly described H. projecta (Fraser, 1938) appears to be different due to the lower length/width ratio of its hydrothecae, as well as on biogeographical grounds (Fraser 1938); 4) the hydrothecae of $H$. rigida (Fraser, 1938) are nearly as broad as deep and, according to Fraser (1938), they are comparatively shorter.

\section{Hincksella neocaledonica sp. nov. urn:1sid:zoobank.org:act:69FDB75D-8E59-4CFB-9387-35B0C1B1D65F}

Fig. 5E-F; Table 3

\section{Diagnosis}

Stems simple, monosiphonic, divided into rather long internodes, each bearing a hydrotheca; the latter alternate, long, tubular, facing out- and upward; rim often renovated; surface of hydrotheca densely and finely striated.

\section{Etymology}

Named for its area of occurrence, New Caledonia.

\section{Material examined}

\section{Holotype}

NEW CALEDONIA: campaign Biocal, station DW46, 22 ${ }^{\circ} 53^{\prime}$ S, $167^{\circ} 17^{\prime}$ E, 570-610 m, 30 Aug. 1985; $2.5 \mathrm{~cm}$ high, infertile stem devoid of hydrorhiza (IK-2012-10299).

\section{Description}

The $2.5 \mathrm{~cm}$ high stem fragment is devoid of its hydrorhiza and seems to have been broken off just above its origin from it. Monosiphonic throughout and unbranched; very basal part ( $c a .2 .5 \mathrm{~mm}$ long) ahydrothecate; remainder of stem divided into 21 moderately long, slender and geniculate internodes, 
Table 3. Measurements of new species of Hincksella Billard, 1918, in $\mu \mathrm{m}$.

\begin{tabular}{lccc}
\hline & H. cornuta sp. nov. & H. neocaledonica sp. nov. & H. similis sp. nov. \\
\hline Stem & & & \\
"Internode" length & $1160-1915$ & $925-1420$ & $665-1110$ \\
Diameter at "node" & $310-370$ & $150-215$ & $185-290$ \\
Hydrotheca & & & \\
Adcauline side free & $865-915$ & $680-740$ & $790-1000$ \\
Adcauline side adnate & $590-730$ & $395-420$ & $465-490$ \\
Abcauline side & $1135-1270$ & $900-1010$ & $1010-1235$ \\
Diameter at rim & $345-370$ & $275-300$ & $290-320$ \\
Gonotheca & & & - \\
Length & $1245-1355(\mathrm{w} / \mathrm{o}$ spines $)$ & - & - \\
& $1395-1455(\mathrm{w} /$ spines $)$ & - & $(15.0-16.8) \times(5.4-6.1)$ \\
$\quad$ Maximum width & $655-730$ & & \\
Cnidome & & & \\
Large capsules & $(17.5-20.3) \times(5.7-6.8)$ & $(17.5-19.3) \times(5.7-6.4)$ & \\
\hline
\end{tabular}

by means of transverse nodes; perisarc of internodes smooth; a distally-placed hydrotheca per internode. Hydrothecae alternate, tubular, adnate for one-third of adcauline length, facing up- and outward, and oriented at an angle of $c .45^{\circ}$ with internode; free adcauline wall nearly straight to imperceptibly convex; abcauline wall convex at inflexion point, then straight and parallel to its free adcauline counterpart; perisarc of hydrotheca finely and densely striated throughout; rim often renovated; aperture circular, perpendicular to long axis of hydrotheca. Gonotheca unknown. Large, parallel-walled macrobasic heteronemes (none seen discharged), with either straight or slightly curved axes and rounded ends, common in coenosarc.

\section{Remarks}

The alternate, long, tubular, non-operculate hydrothecae and the large nematocysts scattered in the coenosarc place this species, with little doubt, in the genus Hincksella Billard, 1918. It superficially resembles H. pusilla (Ritchie, 1910) (see Galea \& Ferry 2015 for taxonomical considerations) through the shape of its internodes and hydrothecae. However, Ritchie's species is comparatively smaller (Galea 2010: table 3) and the perisarc of its hydrothecae is smooth throughout.

Hincksella similis sp. nov. urn:lsid:zoobank.org:act:DBF94D6B-02BA-4364-B599-A411A95D8EC5

Fig. 5G-H; Table 3

\section{Diagnosis}

Stems simple, monosiphonic; nodes indistinct; each internode with a distal hydrotheca; the latter long, tubular, distinctly facing outward, finely and densely striated on free adcauline wall and lower part of abcauline wall.

\section{Etymology}

From the Latin similis, meaning "similar", on account of its resemblance to H. pusilla Ritchie, 1910. 


\section{Material examined}

\section{Holotype}

NEW CALEDONIA: campaign Norfolk 1, station DW1722, 23ำ18' S, 168 $18^{\circ}$ ' E, 540 m, 26 Jun. 2001; sterile, $2.2 \mathrm{~cm}$ high stem (IK-2012-10300).

\section{Description}

Colony erect, $2.2 \mathrm{~cm}$ high, arising from creeping, tortuous, branching stolon. Stem monosiphonic, unbranched; basal part $9 \mathrm{~mm}$ long, ahydrothecate; remainder of stem divided by means of indistinct nodes; each equivalent of internode rather short, slightly geniculate to almost collinear, each bearing a hydrotheca distally. Hydrothecae tubular, given off at an angle of $c .65-70^{\circ}$ with internode, long axis slightly sigmoid; abcauline wall markedly curved where hydrotheca becomes free; aperture rounded, rim even, slightly flared; renovations occasional; perisarc of hydrotheca finely and densely striated, especially on free adcauline side and proximal part of abcauline wall. Gonotheca unknown. Large macrobasic heteronemes (none seen discharged), with parallel walls and rounded ends, and with straight or slightly curved longitudinal axes, occur abundantly in coenosarc.

\section{Remarks}

The alternate, long, tubular, non-operculate hydrothecae and the large nematocysts scattered in the coenosarc place this species, with little doubt, in the genus Hincksella Billard, 1918. This species resembles both $H$. pusilla Ritchie, 1910, through the shape of its hydrothecae, and $H$. neocaledonica sp. nov. through their striations. However, the former is a much smaller species (see dimensions in Galea 2010: table 3), while the latter has comparatively longer and more geniculate internodes, its hydrothecae are given off at more acute angles, their free part is shorter, and the striations extend over the whole perisarc of the colony.

\section{Acknowledgements}

I am indebted to Philippe Bouchet and Pierre Lozouet, both of MNHN, for giving me access to the material described in this work. I am grateful to Dale Calder (Royal Ontario Museum, Toronto, Canada) for unhesitatingly giving his best advice on some systematic issues dealt with in the present work, as well as for providing useful suggestions related to subtleties of English wording. Thanks are also due to two anonymous reviewers for comments on an earlier version of this work. Gratitude is extended to Danny Eibye-Jacobsen (Zoological Museum, Natural History Museum of Denmark, Copenhagen) for handling the editing. This study was undertaken with no financial support.

\section{References}

Allman G.J. 1888. Report on the Hydroida Dredged by H.M.S. Challenger during the Years 1873-76. Part II. - The Tubularinae, Corymorphinae, Campanularinae, Sertularinae and Thalamophora. Report on the Scientific Results of the Voyage of H.M.S. Challenger during the Years 1873-76, Zoology 23 (70), London.

Ansín Agís J., Vervoort W. \& Ramil F. 2009. Hydroids of the family Halopterididae (Cnidaria, Hydrozoa) collected in the western Pacific by various French expeditions. Zoosystema 31: 33-61. http://dx.doi. org/10.5252/z2009n1a3

Ansín Agís J., Vervoort W. \& Ramil F. 2014. Hydroids of the families Kirchenpaueriidae Stechow, 1921 and Plumulariidae McCrady, 1859 (Cnidaria, Hydrozoa) collected in the Western Pacific Ocean by various French Expeditions. Zoosystema 36: 789-840. http://dx.doi.org/10.5252/z2014n4a6

Bouchet P., Héros V., Lozouet P. \& Maestrati P. 2008. A quarter-century of deep-sea malacological exploration in the South and West Pacific: where do we stand? How far to go? In: Héros V., Cowie R.H. 
\& Bouchet P. (eds) Tropical Deep-Sea Benthos Vol. 25: 9-40. Mémoires du Muséum national d'Histoire naturelle 196, Muséum national d'Histoire naturelle, Paris.

Bouillon J., Gravili C., Pagès F., Gili J.M. \& Boero F. 2006. An Introduction to Hydrozoa. Mémoires du Muséum national d'Histoire naturelle 194, Muséum national d'Histoire naturelle, Paris.

Fraser C.M. 1938. Hydroids of the 1934 Allan Hancock Pacific Expedition. Allan Hancock Pacific Expeditions 4: 1-105. Available from http://www.biodiversitylibrary.org/item/26529\#page/13/mode/1up [accessed 5 Jul. 2015]

Galea H.R. 2007. Hydroids and hydromedusae (Cnidaria: Hydrozoa) from the fjords region of southern Chile. Zootaxa 1597: 1-116.

Galea H.R. 2008. On a collection of shallow-water hydroids (Cnidaria: Hydrozoa) from Guadeloupe and Les Saintes, French Lesser Antilles. Zootaxa 1878: 1-54.

Galea H.R. 2010. Additional shallow-water thecate hydroids (Cnidaria: Hydrozoa) from Guadeloupe and Les Saintes, French Lesser Antilles. Zootaxa 2570: 1-40.

Galea H.R. 2013. New additions to the shallow-water hydroids (Cnidaria: Hydrozoa) from the French Lesser Antilles: Martinique. Zootaxa 3686: 1-50. http://dx.doi.org/10.11646/zootaxa.3686.1.1

Galea H.R. \& Ferry R. 2015. Notes on some hydroids (Cnidaria) from Martinique, with descriptions of five new species. Revue Suisse de Zoologie 122 (2) (in press).

Millard N.A.H. 1958. Hydrozoa from the coasts of Natal and Portuguese East Africa. Part I. Calyptoblastea. Annals of the South African Museum 44: 165-226. Available from http://www.biodiversitylibrary. org/item/127012\#page/201/mode/1up [accessed 5 Jul. 2015]

Millard N.A.H. 1967. Hydroids from the south-west Indian Ocean. Annals of the South African Museum 50: 169-194. http://www.biodiversitylibrary.org/item/127146\#page/237/mode/1up [accessed 5 Jul. 2015]

Peña Cantero A.L. \& Vervoort W. 2003a. Species of Staurotheca Allman, 1888 (Cnidaria: Hydrozoa: Sertulariidae) from US Antarctic expeditions, with the description of three new species. Journal of Natural History 37: 2653-2722. http://dx.doi.org/10.1080/00222930210155701

Peña Cantero A.L. \& Vervoort W. 2003b. Sertularia echinocarpa Allman, 1888, an unexpected new species of Staurotheca Allman, 1888 (Cnidaria, Hydrozoa, Sertulariidae). Zoologische Mededelingen 77 (32): 537-543.

Peña Cantero A.L. \& Vervoort W. 2010. Species of Acryptolaria Norman, 1875 (Cnidaria, Hydrozoa, Lafoeidae) collected in the Western Pacific by various French expeditions, with the descriptions of nineteen new species. Zoosystema 32: 267-332. http://dx.doi.org/10.5252/z2010n2a5

Peña Cantero A.L., García Carrascosa A.M. \& Vervoort W. 1999. Two new species of Staurotheca Allman, 1888 (Cnidaria, Hydrozoa, Sertulariidae) from the Scotia Sea (Antarctica). Polar Biology 21: 155-165. http://dx.doi.org/10.1007/s003000050347

Peña Cantero A.L., Svoboda A. \& Vervoort W. 1997. Species of Staurotheca Allman, 1888 (Cnidaria: Hydrozoa) from recent antarctic expeditions with R.V. Polarstern, with the description of six new species. Journal of Natural History 31: 329-381. http://dx.doi.org/10.1080/00222939700770171

Vervoort W. 1993. Cnidaria, Hydrozoa, Hydroida: Hydroids from the western Pacific (Philippines, Indonesia and New Caledonia) I. Sertulariidae (Part 1). In: Crosnier A. (ed.) Résultats des Campagnes MUSORSTOM 11: 89-298. Mémoires du Muséum national d'Histoire naturelle 158, Muséum national d'Histoire naturelle, Paris. 
Vervoort W. \& Watson J.E. 2003. The Marine Fauna of New Zealand: Leptothecata (Cnidaria: Hydrozoa) (Thecate Hydroids). NIWA Biodiversity Memoirs 119, National Institute of Water and Atmospheric Research, Wellington.

Manuscript received: 13 May 2015

Manuscript accepted: 17 June 2015

Published on: 31 August 2015

Topic editor: Rudy Jocqué

Desk editor: Danny Eibye-Jacobsen

Printed versions of all papers are also deposited in the libraries of the institutes that are members of the EJT consortium: Muséum National d'Histoire Naturelle, Paris, France; Botanic Garden Meise, Belgium; Royal Museum for Central Africa, Tervuren, Belgium; Natural History Museum, London, United Kingdom; Royal Belgian Institute of Natural Sciences, Brussels, Belgium; Natural History Museum of Denmark, Copenhagen, Denmark. 